\title{
A novel A2 allele found in Leishmania (Leishmania) infantum chagasi
}

\author{
Novo alelo do gene A2 descrito em Leishmania (Leishmania) infantum chagasi \\ Trícia Maria Ferreira de Sousa Oliveira ${ }^{1}$; Elton José Rosas de Vasconcelos²; \\ Andréa Cristina Higa Nakaghi³; Tânia Paula Aquino Defina²; Márcia Mariza Gomes Jusi³; \\ Cristiane Divan Baldani ${ }^{4}$; Ângela Kaysel Cruz²; Rosangela Zacarias Machado ${ }^{3 *}$
}

\begin{abstract}
${ }^{1}$ Departamento de Zootecnia, Faculdade de Zootecnia e Engenharia de Alimentos, Universidade de São Paulo - USP
${ }^{2}$ Laboratório de Parasitologia Molecular, Departamento de Biologia Celular e Molecular e Bioagentes Patogênicos, Faculdade de Medicina de Ribeirão Preto, Universidade de São Paulo - USP

${ }^{3}$ Laboratório de Imunoparasitologia, Departamento de Patologia Veterinária, Faculdade de Ciências Agrárias e Veterinária, Universidade Estadual Paulista - UNESP

${ }^{4}$ Instituto de Veterinária, Universidade Federal Rural do Rio de Janeiro - UFRRJ
\end{abstract}

Received September 24, 2010

Accepted November 5, 2010

\begin{abstract}
Visceral leishmaniasis (VL) is a widely spread zoonotic disease. In Brazil the disease is caused by Leishmania (Leishmania) infantum chagasi. Peridomestic sandflies acquire the etiological agent by feeding on blood of infected reservoir animals, such as dogs or wildlife. The disease is endemic in Brazil and epidemic foci have been reported in densely populated cities all over the country. Many clinical features of Leishmania infection are related to the host-parasite relationship, and many candidate virulence factors in parasites that cause VL have been studied such as A2 genes. The A2 gene was first isolated in 1994 and then in 2005 three new alleles were described in Leishmania (Leishmania) infantum. In the present study we amplified by polymerase chain reaction (PCR) and sequenced the A2 gene from the genome of a clonal population of $L$. (L.) infantum chagasi VL parasites. The $L$. (L.) infantum chagasi A2 gene was amplified, cloned, and sequenced in. The amplified fragment showed approximately $90 \%$ similarity with another A2 allele amplified in Leishmania (Leishmania) donovani and in L. (L.) infantum described in literature. However, nucleotide translation shows differences in protein amino acid sequence, which may be essential to determine the variability of A2 genes in the species of the $L$. $(L$.$) donovani complex and represents an additional tool$ to help understanding the role this gene family may have in establishing virulence and immunity in visceral leishmaniasis. This knowledge is important for the development of more accurate diagnostic tests and effective tools for disease control.
\end{abstract}

Keywords: Leishmania (Leishmania) infantum chagasi, A2 gene, allele, sequencing.

\section{Resumo}

A leishmaniose visceral (LV) é uma zoonose amplamente disseminada, causada no Brasil pela Leishmania (Leishmania) infantum chagasi. Flebotomíneos vetores adquirem o agente etiológico, alimentando-se do sangue de animais contaminados, como cachorros ou animais selvagens. A doença é endêmica no Brasil, e focos de epidemia são relatados em cidades densamente povoadas por todo o país. Muitas manifestações clínicas relacionadas à infecção por Leishmania estão ligadas à relação parasitohospedeiro, e vários possíveis fatores de virulência dos parasitas, que causam a LV, são alvos de estudo, tais como os genes A2. O gene A2 foi isolado pela primeira vez em 1994 e, em seguida, em 2005, três novos alelos foram descritos em Leishmania (Leishmania) infantum. No presente estudo, um fragmento do gene A2 de uma população clonal de L. (L.) infantum chagasi foi amplificado por PCR e sua sequência de nucleotídeos determinada. O fragmento mostrou $90 \%$ de similaridade com alelos do gene A2 de Leishmania (Leishmania) donovani e de L. (L.) infantum, descritos na literatura. Entretanto, a tradução da sequência de nucleotídeos mostra diferenças na sequência de aminoácidos da proteína, que podem ser essenciais em determinar a variabilidade do gene $\mathrm{A} 2$ em espécies do complexo $L$. (L.) donovani e representa uma ferramenta adicional na compreenssáo do papel dessa família de genes na virulência e imunidade da leishmaniose visceral. O conhecimento dessa variação é importante para o desenvolvimento de testes diagnósticos mais precisos e ferramentas mais eficazes no controle da doença.

Palavras-chave: Leishmania (Leishmania) infantum chagasi, gene A2, alelo, sequenciamento.

\footnotetext{
*Corresponding author: Rosangela Zacarias Machado

Departamento de Patologia Veterinária, Faculdade de Ciências Agrárias e

Veterinárias, Universidade Estadual Paulista - UNESP,

Via de Acesso Prof. Dr. Paulo Donato Castellane, s/n,

CEP 14884-900, Jaboticabal - SP, Brazil;

e-mail: zacarias@fcav.unesp.br
} 


\section{Introduction}

Visceral leishmaniasis (VL) is widespread in tropical and subtropical areas of Latin America, Europe, Africa and Asia. In the New World, the disease is caused by L. (L.) infantum chagasi being the sandfly Lutzomyia longipalpis its main vector (MELO et al., 2009). Peridomestic sandflies acquire the etiological agent $L$. (L.) infantum chagasi - which some authors consider to be the same species as L. (L.) infantum (MAURÍCIO et al., 1999) -, by feeding on blood of infected reservoir animals such as dogs or wildlife. Infected sandflies represent great danger to surrounding human populations because transmission to non-infected hosts can cause severe disease that may be fatal if not promptly treated (TESH, 1995). In Brazil, canine visceral leishmaniasis (CVL) has become a serious public health problem due to the growing number of urban cases and new foci (SILVA et al., 2001; GONTIJO; MELO, 2004; NASCIMENTO et al., 2008). From the epidemiological standing point, CVL is more important than human disease due to its higher prevalence and greater number of parasites in the skin, which can favors vector infection (TRAVI et al., 2001; VERÇOSA et al., 2008).

Clinical signs in CVL depend on the immune response, which is directly associated to the host's genetic factors. Humoral and cellular immune response are involved, and severity and clinical manifestations depends on a balance between these two systems, parasite tropism and virulence (CIARAMELLA et al., 1997; HONORE et al., 1998; GARIN et al., 2001). Among candidate virulence factors in parasites that cause $\mathrm{VL}$ are the $\mathrm{A} 2$ genes (ZHANG; MATLASHEWSKI, 1997, 2001).

A2 genes consist of a family of genes that are abundantly transcribed and translated during the amastigote phase in leishmanias from the Donovani complex whereas their messenger RNA and protein are not present in the promastigote phase (CHAREST; MATLASHEWSKI, 1994; GHEDIN et al., 1997; ZHANG; MATLASHEWSKI, 2001; FARAHMAND et al., 2008). The A2 genes of $L$. (L.) donovani are composed predominantly of a sequence encoding 10 amino acids that may be repeated 40 to 90 times depending on each specific gene (CHAREST; MATLASHEWSKI, 1994; GHOSH; ZHANG; MATLASHEWSKI, 2001).

A2 genes share similarities with the $S$ antigen expressed by Plasmodium falciparum (CHAREST; MATLASHEWSKI, 1994), and a possible role for the structure/functionality of A2 genes in the cutaneous or visceral tropism of Leishmania parasites in L. major and L. (L.) infantum has been studied and suggested (GHEDIN et al., 1997; ZHANG et al., 2003; GARIN et al., 2005). Species that cause Old and New World VL, L. (L.) donovani, L. (L.) infantum, and L. (L.) infantum chagasi, and New World cutaneous leishmaniasis (CL), L. mexicana and L. amazonensis, have A2 genes in their chromosomes (GHEDIN et al., 1997). In $L$. major $\mathrm{A} 2$ is considered a pseudogene, and the introduction of $L$. (L.) donovani A2 gene in this species allowed its survival in visceral organs of mice (ZHANG et al., 2003). The gene was isolated and expressed for the first time in $L$. (L.) donovani (CHAREST; MATLASHEWSKI, 1994, ZHANG et al., 1996). In 2005, three new alleles were described in $L$. (L.) infantum (GARIN et al., 2005). There is evidence showing that A2 are stress response proteins, important to $L$. (L.) donovani survival in visceral organs (McCALL; MATLASHEWSKI, 2010). Sera from humans and dogs naturally infected with $L$. (L.) infantum chagasi reacted in a serological assay using A2 recombinant proteins (GHEDIN et al., 1997; CARVALHO et al., 2002).

The present study describes an A2 allele found in a L. (L.) infantum chagasi strain, isolated from a dog with VL treated in the Veterinary Hospital of Universidade Estadual Paulista in the city of Jaboticabal, São Paulo, Southeastern Brazil. We amplified, cloned, and sequenced a $743 \mathrm{bp}$ fragment. The amplified fragment showed approximately $90 \%$ similarity with another A2 allele amplified in L. (L.) donovani (CHAREST; MATLASHEWSKI, 1994) and L. (L.) infantum (GARIN et al., 2005).

\section{Material and Methods}

\section{L. (L.) infantum chagasi strain}

A strain of L. (L.) infantum chagasi was isolated from a dog's bone marrow sample from the town of Olympia, São Paulo. The animal was examined at the Veterinary Hospital of FCAV-UNESP, Jaboticabal, São Paulo, with clinical symptoms of CVL and the strain obtained was used to isolate the A2 gene. The parasites were maintained in RPMI-1640 medium (Sigma-Aldrich, St. Louis, USA) supplemented with $10 \%$ heat-inactivated fetal bovine serum (FBS; Gibco, Canyon City, USA) at $25^{\circ} \mathrm{C}$ and strain characterization was made by polymerase chain reaction (PCR) and restriction fragment length polymorfism (PCR-RFLP) technique (CORTES et al., 2004; ANDRADE et al., 2006).

\section{DNA extraction}

L. (L.) infantum chagasi genomic DNA extraction was adapted from a proteinase $\mathrm{K}$ extraction previously described (CLER et al., 2006). Briefly, promastigotes from axenic culture were harvested and then resuspended in $350 \mu \mathrm{L}$ of TE buffer (Tris $10 \mathrm{mM}$; EDTA $1 \mathrm{mM}, \mathrm{pH} 8.0)$ and $20 \mu \mathrm{L}$ of SDS $10 \%$. Ten $\mu \mathrm{L}$ of proteinase $\mathrm{K}$ $\left(10 \mu \mathrm{g} \cdot \mu \mathrm{L}^{-1}\right)$ were subsequently added, and microtubes were incubated for 36 hours at $37^{\circ} \mathrm{C}$. After incubation, DNA was extracted with a standard procedure (phenol/chloroform/isoamilic alcohol) (25:24:1) and DNA precipitation was done using $\mathrm{NaCl} /$ ethanol procedure (SAMBROOK; FRITSCH; MANIATIS, 2001). The extracted DNA was dissolved in $20 \mu \mathrm{L}$ of sterile water.

\section{PCR}

Amplification of $L$. (L.) infantum chagasi DNA (50 ng) matrix was done using L2/R3 primers(5'T T G G CA A T G C G A G C G T C A C A G T C / 5 ' CAACGCGTACGATAATGCCACA) that correspond to the 5' end position 16301 and 16603 of the reverse complementary strand of the AC010851 sequence, respectively (GARIN et al., 2005). In addition to DNA, PCR was performed in a reaction mixture of $25 \mu \mathrm{L}$ containing $2.5 \mu \mathrm{L}$ PCR buffer $10 \times(200 \mathrm{mM}$ 
Tris-HCl, $\mathrm{pH}$ 8.4, $500 \mathrm{mM} \mathrm{KCl),} 3 \mathrm{mM} \mathrm{MgCl} 2,200 \mu \mathrm{M}$ each dNTP (dTTP, dATP, dGTP, dCTP, Eppendorf), $0.5 \mu \mathrm{M}$ of each primer (Invitrogen, Carlsbad, USA) and $1 \mathrm{U}$ recombinant Taq polymerase (Invitrogen, Carlsbad, USA). L2/R3-PCR conditions consisted of denaturation for 3 minutes at $94^{\circ} \mathrm{C}$, followed by 35 amplification cycles at $94^{\circ} \mathrm{C}$ for 1 minute, 1 minute at $58^{\circ} \mathrm{C}$, 1 minute at $72{ }^{\circ} \mathrm{C}$, then one cycle at $72{ }^{\circ} \mathrm{C}$ for 5 minutes. A total of $5 \mu \mathrm{L}$ of PCR product was electrophoresed in $1 \%$ agarose gel in the presence of ethidium bromide, and visualized under UV light. A 100 bp ladder (Invitrogen, Carlsbad, USA) was used as MW marker.

\section{DNA libraries and sequencing}

L2/R3-PCR products were purified with GeneClean II (QbioGene, 1001-400, Carlsbad, USA). The insertion of PCR products into pGEM-T Easy Vector Systems (Promega, Madison, USA), transformation of Escherichia coli DH10B competent cells, and cloning were performed using a PCR Cloning Kit (Promega, Madison, USA) as described by the manufacturer. One hundred and ninety-two clones were obtained and two A2-containing clones identified by sequencing. The plasmid DNA was extracted by alkaline lysis (SAMBROOK; FRITSCH; MANIATIS, 2001) and sequenced by the Sanger method with M13 forward and M13 reverse (Promega, Madison, USA) primers set using the BigDye Terminator Cycle Sequencing Ready Reaction Kit (Perkin-Elmer Applied Biosystems, Courtaboeuf, France) on a ABI PRISM 3100 DNA Analyzer (Applied Biosystems, Courtaboeuf, France).

\section{Sequence analysis}

Sequences obtained were then analyzed by Phred (EWING et al., 1998) and cross-match (www.phrap.org) algorithms to perform base calling and trimming $(\mathrm{Q} \geq 20)$ and to mask cloning vector bases, respectively. After this filtering process the sequences were submitted to BlastN and BlastX (ALTSCHUL et al., 1990) analysis against non-redundant (nr) NCBI database and the L. (L.) infantum v3.0a database (ftp://ftp.sanger.ac.uk/pub4/ pathogens/L_infantum/DATASETS/). The $L$. ( $L$.) infantum chagasi A2 nucleotide sequence was translated by dna2pep algorithm (http://www.cbs.dtu.dk/services/VirtualRibosome/) and we took the same translation frame that was observed on BlastX best hits.

Global multiple alignments for DNA and protein sequences of the identified $L$. ( $L$.) infantum chagasi $\mathrm{A} 2$ gene, three $\mathrm{A} 2$ alleles from $L$. (L.) infantum (GARIN et al., 2005) and a $L$. (L.) donovani A2 gene (CHAREST; MATLASHEWSKI, 1994) were performed using ClustalW algorithm (THOMPSON; HIGGINS, 1994) and edited by BoxShade (http://www.ch.embnet.org/software/ BOX_form.html). The identity percentages among sequences on global multiple alignments were measured by the alistat algorithm included in the HMMER package (DURBIN et al., 1998).

\section{GeneBank accession numbers}

The accession number for the $\mathrm{A} 2$ gene isolated in $L$. (L.) infantum chagasi described in this study is [GenBank:GQ290460]; the accession numbers for $L .(L$.$) infantum A2 alleles II, III, and IV$ are [GenBank:AY255807, GenBank: AY255808, and GenBank: AY255809], respectively (GARIN et al., 2005), and the accession number for $L$. (L.) donovani is [GenBank:S69693] (CHAREST; MATLASHEWSKI, 1994).

\section{Results and Discussion}

Direct sequencing and analyses of L2R3 PCR products from crude genomic DNA of $L$. (L.) infantum chagasi could not be performed. These PCR products resolved in a pattern of multiple bands (Figure 1), and thus A2 sequence was obtained from clone libraries as described in Methods.

An identical A2-gene sequence of 743 nucleotides was isolated in two clones from the genomic library of $L$. ( $L$.) infantum chagasi. Blast $\mathrm{N}$ analysis of this new sequence and other four different VL A2 alleles, against all annotated CDSs from $L$. (L.) infantum genome version 3.0a, showed gene LinJ22_V3.0670 as the best hit for all five query sequences. Our sequence showed $95 \%$ similarity with this gene; alleles isolated from $L$. (L.) infantum showed 97\% (Type II), 91\% (Type III), and 92\% (Type IV) similarity; and $L$. (L.) donovani A2 allele showed $87 \%$ similarity (Table 1 ). However, considering only the coding region $L$. (L.) infantum chagasi has the same stop codon TAA present in $L$. (L.) infantum (Type II, III, and IV) (Figure 2), the sequence translated to an amino acid sequence has $342 \mathrm{bp}$ and is $98,9 \%$ identical to L. (L.) infantum (Type II) (Figure 3).

Since the first description of $\mathrm{A} 2$ gene, the existence of at least five closely related genes (A2 series) has been investigated (CHAREST; MATLASHEWSKI, 1994; ZHANG; MATLASHEWSKI, 2001). Zhang et al. (1996) described A2 as a multigene family, which expresses different sizes of 10 -amino acid repeats. Three different A2-gene alleles in a genetically pure parasite clonal lineage (L. infantum MHOM/FR/92/LEM 2385 clone-1) were subsequently isolated, providing additional evidence of the existence of multiple A2 genes (GARIN et al., 2005) and a different A2 sequence is here described in $L$. ( $L$.) infantum chagasi. Allele types I, II, and III described in the pure clonal lineage

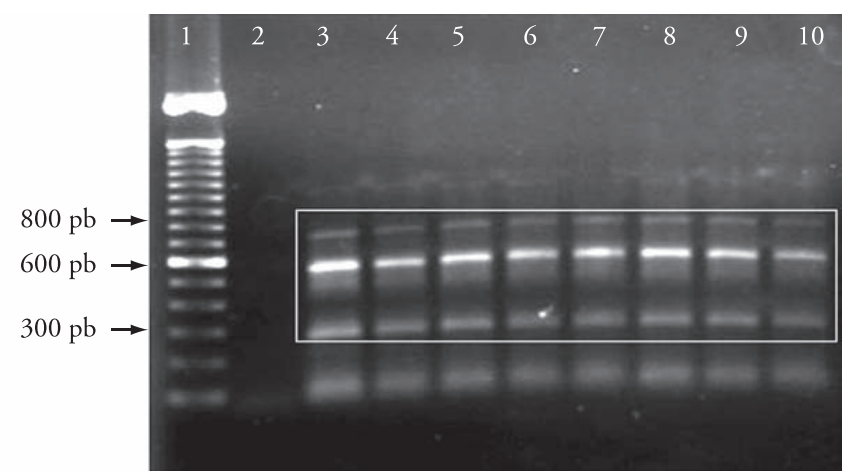

Figure 1. PCR electrophoresis patterns. Electrophoretic pattern of PCR products obtained from $L$. (L.) infantum chagasi genomic DNA. Each slot corresponds to a single sample amplified using the same PCR mix. The framed area corresponds to the expected sizes for the $\mathrm{A} 2$ gene. 


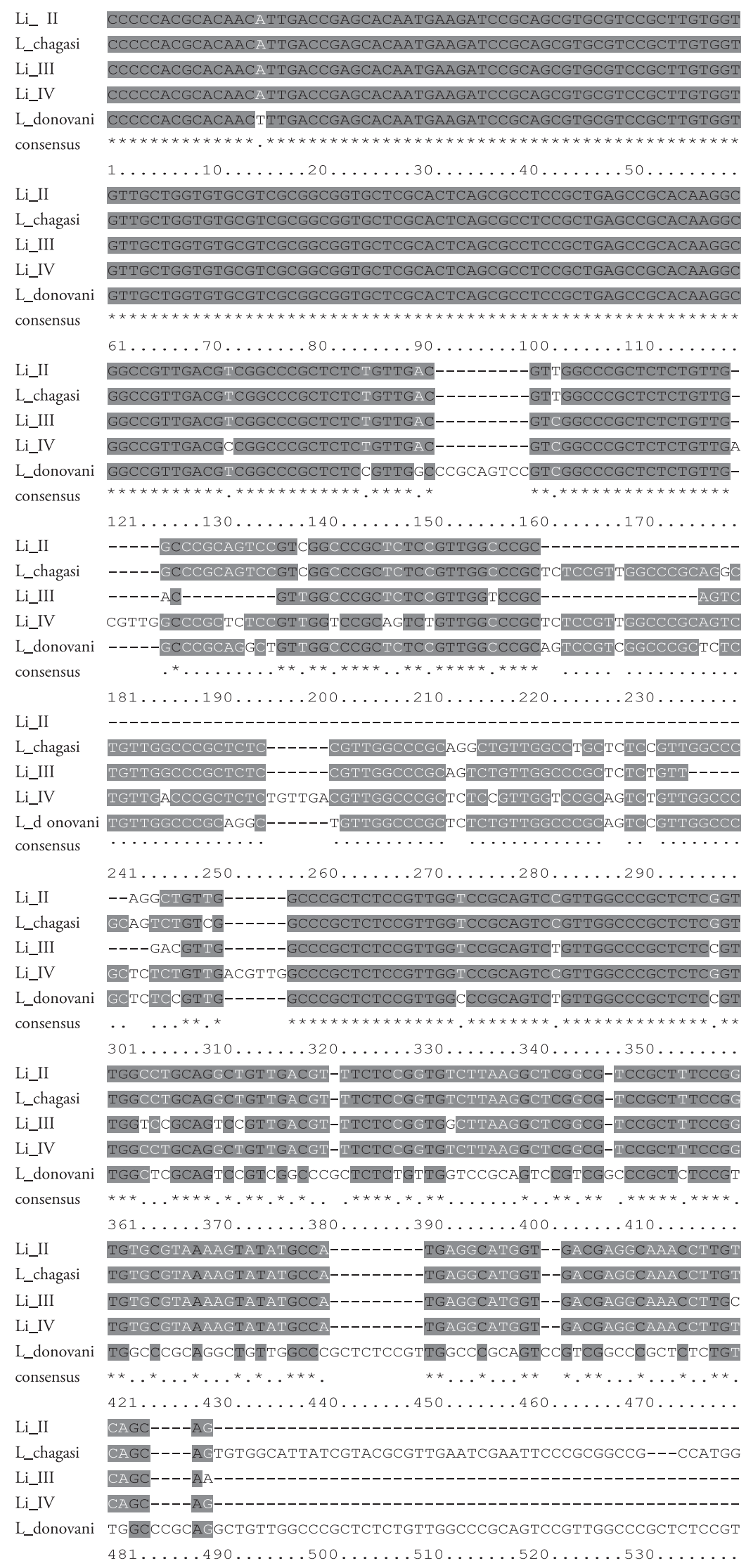

Figure 2. Multiple alignment of A2 nucleotide sequences from $L$. (L.) infantum (allele types II, III, and IV), $L$. $(L$.) donovani and L. (L.) infantum chagasi. 
Table 1. BlastN analysis of different A2 alleles. BlastN analysis of five different VL A2 alleles against all annotated CDSs in $L$. (L.) infantum genome version 3.0a. The LinJ22_V3.0670 gene was the best hit for all five query sequences. Queries Li_II, Li_III, and Li_IV are $L$. ( $L$.) infantum A2 alleles described by Garin et al. (2005), and query $L$. donovani is the A2 gene from $L$. (L.) donovani described by Charest and Matlashewski (1994), and query L. chagasi is the V allele herein described.

\begin{tabular}{lccccccccc}
\hline \multicolumn{1}{c}{ Query id } & Subject id & \% identity & $\begin{array}{c}\text { Alignment } \\
\text { length }\end{array}$ & q. start & q. end & s. start & s. end & e-value & Bit \\
\hline Li_II & LinJ22_V3.0670 & 97 & 202 & 29 & 230 & 1 & 202 & $2,00 \mathrm{E}-97$ \\
Li_III & LinJ22_V3.0670 & 91 & 274 & 29 & 302 & 1 & 253 & $1,00 \mathrm{E}-109$ \\
Li_IV & LinJ22_V3.0670 & 92 & 340 & 29 & 368 & 1 & 319 & $1,00 \mathrm{E}-141$ \\
L_donovani & LinJ22_V3.0670 & 87 & 574 & 29 & 590 & 1 & 556 & $1,00 \mathrm{E}-165$ \\
L_chagasi & LinJ22_V3.0670 & 95 & 194 & 54 & 247 & 1 & 193 & $3,00 \mathrm{E}-85$ \\
\hline
\end{tabular}

(q.start: start of query sequence; q. end: end of query sequence; s. start: start of sequence; s.end: end of sequence).

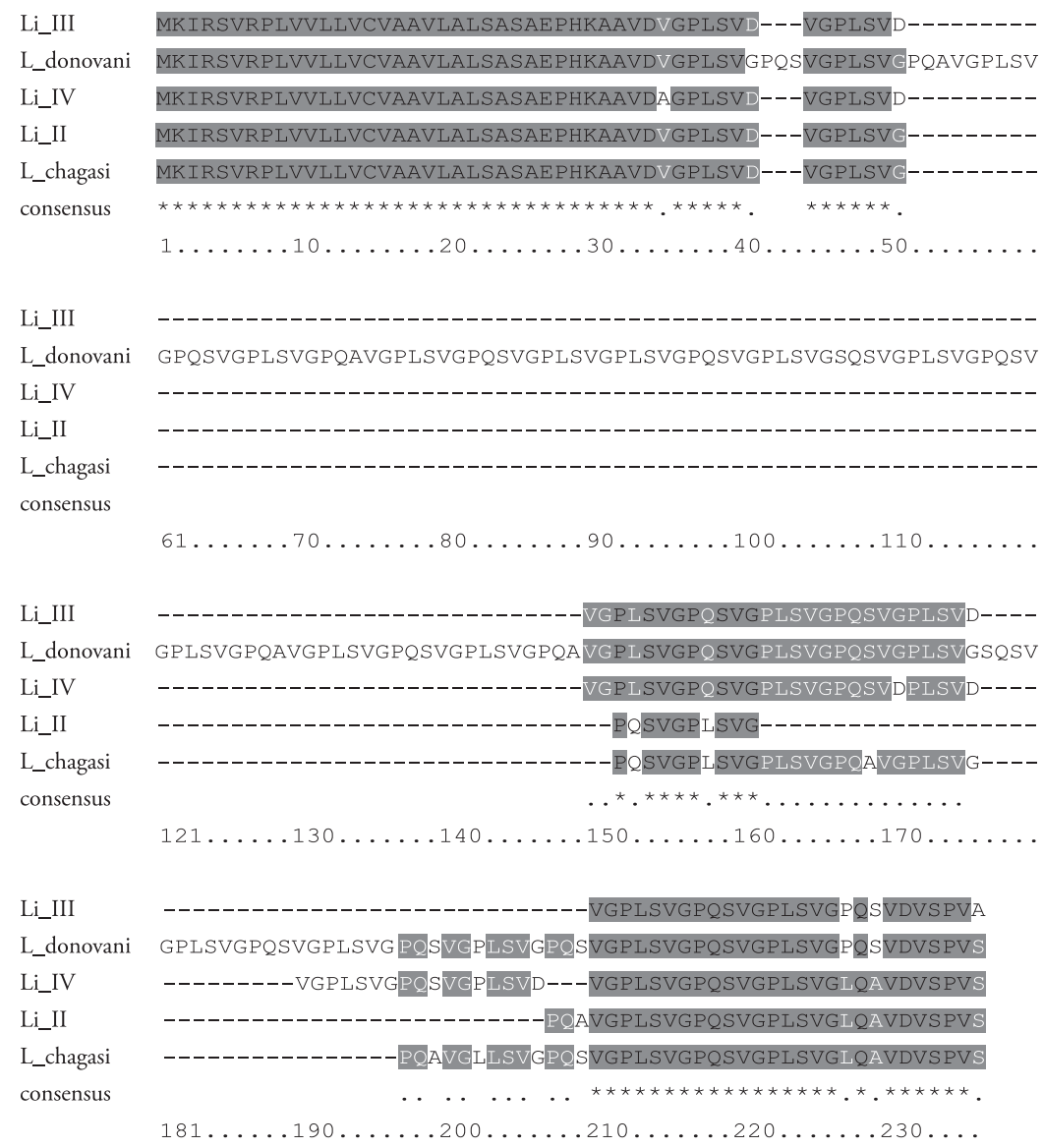

Figure 3. Multiple alignments of A2 amino acid sequences (translated nucleotide sequences by dna2pep algorithm.) from $L$. (L.) infantum (allele types II, III, and IV), L. (L.) donovani and L. (L.) infantum chagasi.

L. (L.) infantum MHOM/FR/92/LEM 2385 clone-1 differ only in the number and arrangements of the repeated motifs at the 3 ' end variable region of the gene (GARIN et al., 2005) and in all cases, only strains from the $L$. $(L$.) donovani complex causing VL in Old World were sequenced.

In the present study, we used a clinical isolate of a $L$. (L.) infantum chagasi infected dog to identify and sequence an A2 gene copy, corroborating previous findings that the A2 family of VL species is a multiple gene family.

The present study evidenced a divergent A2 gene in the $L$. (L.) infantum chagasi strain when compared to the $L$. (L.) infantum and $L$. (L.) donovani A2 alleles first identified. A comparative analysis of the A2 gene isolated from L. (L.) donovani, three A2-gene alleles isolated from L. (L.) infantum (Type II, III, and IV), and the A2 gene isolated from $L$. (L.) infantum chagasi herein described showed that the 5' ORF is highly preserved (Figure 2) in both nucleotide and amino acid sequences obtained by nucleotide sequence translated by dna2pep algorithm. At the protein level, the sequences aligned had an identity average of $93 \%$, but this analysis showed few differences among the sequences that can cause great changes in protein function. Close to 170 and 200 positions of the alignment ruler (Figure 3 ) there is an alanine residue in $L$. (L.) infantum chagasi sequence instead of a serine residue present in the other A2 sequences analyzed. 
The L. (L.) donovani's A2 protein shows immunogenicity. Significant protection against $L$. (L.) donovani and L. amazonensis infections associated with both humoral and cellular immune responses has been seen when using $\mathrm{A} 2$ as a recombinant protein or a DNA vaccine in BALB/c mice, and more recently in dogs (GHOSH; ZHANG; MATLASHEWSKI, 2001; COELHO et al., 2003; ZANIN et al., 2007; RESENDE et al., 2008; FERNANDES et al., 2008). A recombinant $L$. (L.) tarentolae expressing the $L$. (L.) donovani-specific A2 protein used as a live vaccine against $L$. $(L$.) infantum infection in BALB/c mice has provided evidence of favorable immune response and significant levels of protective immunity against $L$. (L.) infantum infections (MIZBANI et al., 2009).

This study evidences that there are differences in nucleotide sequences, and possible in amino acid of A2 protein sequences, which can be essential to establish specific pathogenic pathways in Leishmania species. In two positions of the C-terminal region on the A2 protein multiple alignment, $L$. (L.) infantum chagasi has an alanine residue while the other $\mathrm{A} 2$ sequences have a serine residue. This change might cause changes in three-dimensional structure of the protein and consequently in its function. Phenotypic effects of the alteration are more drastic, according to the differences in the chemical nature of side chains of amino acid residues, the substitution of an amino acid hydrophilic by one amino acid with hydrophobic side chain of residue, as here described, can cause great changes in functional activity of the protein (NELSON; COX, 2006). Since multiple A2 sequences of varying lengths were observed in different VL isolates by our group and by others, our results may help to determine the variability of A2 genes in the species of the $L$. (L.) donovani complex and represents an additional tool to help us understand the role this family of genes may have in establishing virulence in visceral leishmaniasis. The exact function of A2 protein in Leishmania is still unknown (AZIZI et al., 2009). Gene silencing of A2 in L. (L.) donovani dramatically decreased its viability and pathogenicity in mammalian macrophages (ZHANG; MATLASHEWSKI, 1997). Overexpression of A2 in $L$. major resulted in visceralization of infection (ZHANG; MATLASHEWSKI, 1997; GARIN et al. 2005) and A2 gene was the only virulence factor that was not found in non-pathogenic parasites to human L.(L.) tarentolae (AZIZI et al., 2009), further supporting A2 gene importance in the pathogenesis of leishmaniasis. In Brazil, visceral leishmaniasis is caused by L. (L.) infantum chagasi, and the evidenced differences among A2 genes in species are important to elucidate the role of this gene in VL, which is essential for the development of more accurate diagnostic tests and effective tools for disease control. Studies with southern blotting and protein expression are being conducted with A2 gene isolated in $L$. (L.) infantum chagasi to confirm and better understand the changes found.

\section{Acknowledgements}

We thank Dr. Vanete Thomaz Soccol, from Universidade Federal do Paraná, Curitiba, Brazil, for her help with the classification of $L$. (L.) infantum chagasi. This study was supported by FAPESP grant No. 2005/52678-4.

\section{References}

ALTSCHUL, S. F. et al. Basic local alignment search tool. Journal of Molecular Biology, v. 215, n. 3, p. 403-410, 1990.

ANDRADE, H. M. et al. Use of PCR-RFLP to identify Leishmania species in naturally infected dogs. Veterinary Parasitology, v. 140, n. 3-4, p. 231-238, 2006.

AZIZI, H. et al. Searching for virulence factors in the non-pathogenic parasite to humans Leishmania tarentolae. Parasitology, v. 136, n. 7 , p. 723-735, 2009.

CARVALHO, F. A. et al. Diagnosis of American visceral leishmaniasis in humans and dogs using the recombinant Leishmania donovani A2 antigen. Diagnostic Microbiology and Infectious Disease, v. 43, n. 4, p. 289-295, 2002.

CHAREST, H.; MATLASHEWSKI, G. Developmental gene expression in Leishmania donovani: differential cloning and analysis of an amastigotestage-specific gene. Molecular and Cellular Biology, v. 14, n. 5, p. 2975-2984, 1994.

CIARAMELLA, P. et al. A retrospective clinical study of canine leishmaniasis in 150 dogs naturally infected by Leishmania infantum. Veterinary Record, v. 141, n. 21, p. 539-543, 1997.

CLER, L. et al. A comparison of five methods for extracting DNA from paucicellular clinical samples. Molecular and Cellular Probes, v. 20, n. 3-4, p. 191-196, 2006.

COELHO, E. A. F. et al. Immune Responses Induced by the Leishmania (Leishmania) donovani A2 Antigen, but Not by the LACK Antigen, Are Protective against Experimental Leishmania (Leishmania) amazonensis. Infection and Immunity, v. 71, n. 7, p. 3988-3994, 2003.

CORTES, S. et al. PCR as a rapid and sensitive tool in the diagnosis of human and canine leishmaniasis using Leishmania donovani s.l. - specific kinetoplastid primers. Transactions of the Royal Society of Tropical Medicine and Hygiene, v. 98, n. 1, p. 12-17, 2004.

DURBIN, R. et al. Biological sequence analysis: probabilistic models of proteins and nucleic acids. Cambridge University Press, 1998.

EWING, B. et al. Base-calling of automated sequencer traces using phred.I. Accuracy assessment. Genome Research, v. 8, n. 3, p. 175-185, 1998.

FARAHMAND, M. et al. Expression of A2 proteins in amastigotes of Leishmania infantum produced from canine isolates collected in the district of Meshkinshahr, in north-western Iran. Annals of Tropical Medicine and Parasitology, v. 102, n. 1, p. 81-84, 2008.

FERNANDES, A. P. et al. Protective immunity against challenge with Leishmania (Leishmania) chagasi in beagle dogs vaccinated with recombinant A2 protein. Vaccine, v. 26, n. 46, p. 5888-5895, 2008.

GARIN, Y. J. et al. Virulence of Leishmania infantum is expressed as a clonal and dominant phenotype in experimental infections. Infection and Immunity, v. 69, n. 12, p. 7365-7373, 2001.

GARIN, Y. J. F. et al. A2 gene of Old World cutaneous Leishmania is a single highly conserved functional gene. BMC Infectious Diseases, v. 5, n. 18, p. 1-7, 2005.

GHEDIN, E. et al. Antibody response against a Leishmania donovani amastigote-stage-specific protein in patients with visceral leishmaniasis. Clinical and Diagnostic Laboratory Immunology, v. 4, n. 5, p. 530-535, 1997. 
GHOSH, A.; ZHANG, W. W.; MATLASHEWSKI, G. Immunization with A2 protein results in a mixed Th1/Th2 and a humoral response which protects mice against Leishmania donovani infections. Vaccine, v. 20 , n. $1-2$, p. 59-66, 2001.

GONTIJO, C. M. F.; MELO, M. N. Leishmaniose visceral no Brasil: quadro atual, desafios e perspectivas. Revista Brasileira de Epidemiologia, v. 7, n. 3, p. 338-349, 2004.

HONORE, S. et al. Influence of the host and parasite strain in a mouse model of visceral Leishmania infantum infection. FEMS Immunology and Medical Microbiology, v. 21, n. 3, p. 231-239, 1998.

MAURÍCIO, I. L. et al. Genomic diversity in the Leishmania complex. Parasitology, v. 119, n. 3, p. 237-246, 1999.

McCALL, L. I.; MATLASHEWSKI, G. Localization and induction of the A2 virulence factor in Leishmania: evidence that A2 is a stress response protein. Molecular Microbiology, v. 77, n. 2, p. 518-530, 2010.

MELO, F. A. et al. Hepatic extracellular matrix alterations in dogs naturally infected with Leishmania (Leishmania) chagasi. International Journal of Experimental Pathology, v. 90, n. 5, p. 538-548, 2009.

MIZBANI, A. et al. Recombinant Leishmania tarentolae expressing the A2 virulence gene as a novel candidate vaccine against visceral leishmaniasis. Vaccine, v. 28, n. 1, p. 53-62, 2009

NASCIMENTO, E. L. T. et al. Forum: geographic spread and urbanization of visceral leishmaniasis in Brazil. Postscript: new challenges in the epidemiology of Leishmania chagasi infection. Cadernos de Saúde Pública, v. 24, n. 12, p. 2964-2967, 2008.

NELSON, D. L.; COX, M. M. Lehninger-principles of biochemistry. $4^{\text {th }}$ ed. Sarvier, 2006. 1202 p.

RESENDE, D. M. et al. Epitope mapping and protective immunity elicited by adenovirus expressing the Leishmania amastigote specific A2 antigen: correlation with IFN- $\gamma$ and cytolytic activity by CD8+ T cells. Vaccine, v. 26, n. 35, p. 4585-4593, 2008.

SAMBROOK, J.; FRITSCH, E. F.; MANIATIS, T. Molecular cloning: a laboratory annual. $3^{\text {rd }}$ ed. New York: Cold Spring Harbor Laboratory, Cold Spring Harbor, 2001.
SILVA, E. S. et al. Visceral leishmaniasis in the metropolitan region of Belo Horizonte, state of Minas Gerais, Brazil. Memórias do Instituto Oswaldo Cruz, v. 96, n. 3, p. 285-291, 2001.

TESH, R. B. Control of zoonotic visceral leishmaniasis. Is it time to change strategies? American Journal of Tropical Medicine and Hygiene, v. 52, n. 3, p. 287-292, 1995.

THOMPSON, J. D.; HIGGINS, D. G. Clustal W: improving the sensitivity of progressive multiple sequence alignment through sequence weighting, position-specific gap penalties and weight matrix choice. Nucleic Acids Research,v. 22, n. 22, p. 4673-4680, 1994.

TRAVI, B. L. et al. Canine visceral leishmaniasis in Colombia: relationship between clinical and parasitologic status and infectivity for sand flies. American Journal of Tropical Medicine and Hygiene, v. 64, n. 3, p. 119-124, 2001.

VERÇOSA, B. L. A. et al. Transmission potential, skin inflammatory response and parasitism of symptomatic and asymptomatic dogs with visceral leishmaniasis. BMC Veterinary Research, v. 4, n. 45, 2008.

ZANIN, F. H. C. et al. Evaluation of immune responses and protection induced by $\mathrm{A} 2$ and nucleoside hydrolase $(\mathrm{NH})$ DNA vaccines against Leishmania chagasi and Leishmania amazonensis experimental infections. Microbes and Infection, v. 9, n. 9, p. 1070-1077, 2007.

ZHANG, W. W.; MATLASHEWSKI, G. Loss of virulence in Leishmania donovani deficient in an amastigote-specific protein, A2. Proceedings of the National Academy of Sciences of the United States of America, v. 94, n. 16, p. 8807-8811, 1997.

ZHANG, W. W.; MATLASHEWSKI, G. Characterization of the A2-A2rel gene cluster in Leishmania donovani: involvement of A2 in visceralization during infection. Molecular Microbiology, v. 39, n. 4, p. 935-948, 2001.

ZHANG, W. W. et al. Identification and overexpression of the A2 amastigote-specific protein in Leishmania donovani. Molecular and Biochemical Parasitology, v. 78, n. 1-2, p. 79-90, 1996.

ZHANG, W. W. et al. Comparison of the A2 gene locus in Leishmania donovani and Leishmania major and its control over cutaneous infection. The Journal of Biological Chemistry, v. 278, n. 37, p. 35508-35515, 2003. 